\title{
Risk and Economic Development in the Provision of Public Infrastructure
}

\author{
Frederick Bloetscher \\ Florida Atlantic University, Boca Raton, USA \\ Email: h2o_man@bellsouth.net
}

How to cite this paper: Bloetscher, F. (2018) Risk and Economic Development in the Provision of Public Infrastructure. Journal of Environmental Protection, 9, 973-990. https://doi.org/10.4236/jep.2018.99061

Received: May 8, 2018

Accepted: August 24, 2018

Published: August 27, 2018

Copyright $\odot 2018$ by author and Scientific Research Publishing Inc. This work is licensed under the Creative Commons Attribution International License (CC BY 4.0).

http://creativecommons.org/licenses/by/4.0/

\begin{abstract}
A public water and sewer utility is created to develop safe, reliable and financially self-supporting potable water and sanitary sewage systems which will meet the water and sewerage needs of the areas served by the utility; to ensure that existing and future utility facilities are constructed, operated and managed at the least possible cost to the users without outside subsidies; and to develop a system that is compatible with the area's future growth. To gain efficiencies in operation, these new facilities must be developed in accordance with the latest technical and professional standards to protect the health, safety, and welfare of the citizens served now or in the future. Hence a utility must construct new pipelines, pump stations and other infrastructure, whether that infrastructure is for growth, to improve existing service, or to replace infrastructure that has reached the end of its useful, economic, and/or physical life. In established or stable communities, the replacement of existing infrastructure, where it is no longer economical to operate, is deteriorated to a point where replacement is more cost effective than repairs due to wear, neglect or environmental conditions, or where the infrastructure no longer serves its intended purpose or meets regulatory standards, must be pursued. As a result, many established utilities have capital plans that contain many such replacement projects. The question is how much investment should be made. The intent of this paper is to evaluate investment in infrastructure made by public water and sewer utility systems. What was found among the utilities in Florida that were evaluated was that more than half are underinvesting in their infrastructure. Some are not investing at all although more research is needed because it appears that many utilities make large investments periodically as opposed to using pay-as-you-go methods. Large scale investments like bond issues impact rates. Economies-of-scale remain for large utilities. Smaller utilities compete with larger ones to control rates. The data gathered indicates that utilities are underfunded, and under-invested. To reduce potential health risks, this needs to change. At the same time, trends appear to
\end{abstract}


be a key to assess the potential for at risk utilities. Hence a future project would review data for the past 15 - 20 years for trends, identify patterns of altered investments and denote how the 2008 financial crisis changed the utility finances. A road to recapture lost revenues and make the infrastructure more resilient can then be accomplished.

\section{Keywords}

Water, Sewer, Economy-of-Scale, Utility Finance

\section{Introduction}

At a recent Florida Section of the American Water Works Association meeting, former District of Columbia (DC) Water CEO George Hawkins noted that he was often asked how many jobs DC Water created in the District of Columbia. His answer was "all of them." He was then asked how much DC water contributed to the economic viability of the area and his answer was "all of it". The reality is that infrastructure systems are necessary for any society to function, and the need to provide that infrastructure is understood to result from the efforts of individuals and communities to modify their physical surroundings to improve their comfort, economic development and productivity, and protection from the elements [1] [2].

Since the benefits of infrastructure systems are broad-based, within the public interest, and have huge initial costs and long payback periods, they are generally constructed with public funds. Public finance theory stresses that a basic rationale for government provision of goods and services is that the private market economy is unable or unwilling to accomplish the task-the payback for these types of projects is normally too long for private equity interests. Grimsey and Lewis [3] noted that since World War II, governmental units, federal, state and local, have been the primary constructors of infrastructure projects (albeit less so in the United States with respect to communications and power). The reality is that infrastructure is an investment decision, and the hope is that if infrastructure is built, development and an improved quality of life will follow. The belief has been that good "core" infrastructure will increases the productivity and economic activity, including capital [4], labor and total factor productivity [5], or a combination of factors [6]. During the period from 1973 to 1985, public net investment in infrastructure systems in the United States and Japan averaged $0.3 \%$ and $5.1 \%$ of gross domestic product, while their respective growth rates of real gross domestic output per employed person were $0.6 \%$ and $3.1 \%$ per annum (OECD National Accounts and Historical Statistics).

The data and numerous studies confirm the belief that infrastructure investment spurs economic growth, but defining the exact amount of economic growth created by infrastructure investment is elusive. Over 40 studies have been performed. Arrow and Kurz [7] were the first to develop theoretical work on the 
contribution of infrastructure to output, productivity and welfare, finding a correlation between infrastructure development and economic growth. Borcherding and Deacon [8] found large and statistically significant income elasticities for highway and water-sewer expenditures. Aschauer [9] advanced the concept of using elasticity to show that public investment will induce an increase in the rate of return to private capital and, thereby, to stimulate private investment expenditure. He asserted that that infrastructure expenditures may well have been a key ingredient to the robust performance of the economy in the 1950s and 1960s [10], and suggested that public infrastructure investments are the primary factors in fostering economic growth and productivity improvement [11]. Aschauer [10] and Munnell [12] also found a strong positive relationship between infrastructure and growth. Stephanades [13] and Stephanades and Eagle [14] found that highway spending increases economic growth in urban counties. Eberts [15] concluded with an overall assessment of a positive relationship between public infrastructure and regional growth. Bougheas et al. [16] and Moomaw et al. [17] also found a positive correlation between public infrastructure and economic output in almost all cases, although they suggested that states get greater returns from investing in water and sewer systems than from investing in highways. Periera (2001) [18] found that public investment in water and sewer infrastructure has lower long-term elasticities than all other types of infrastructure (power, communications) except for highways and streets. These analyses are why in difficult times, the federal government has focused on large infrastructure investments-infrastructure is expected to provide immediate jobs, and long-term growth. The most notable examples are the Works Progress Administration (WPA; renamed in 1939 as the Work Projects Administration) projects of the Great Depression and the American Recovery and Reinvestment Act of 2009 (ARRA) legislation of the Great Recession. Both are credited with putting people to work and preventing further economic hardship on the country [19] [20].

At the same time, the amount spent on infrastructure varies with time, economic activity and with population density-urban areas tend to have far more investments in infrastructure than rural areas. In rural communities, the cost to extend water, sewer, roads, etc. are often more per person, than for urban settings. The thought is that the critical mass of urban development permits ongoing investment and maintenance of same, which is paid for by increasing economic activity. But a question remains-does the failure to invest put communities at risk economically, financially and with respect to their infrastructure systems? Munnell and Cook [21] and Eberts [15] suggest underinvestment in public capital may ultimately retard our economic growth. The fear is that deteriorating infrastructure will lead to real job losses throughout the economy. Lower wage workers will be most at risk of job loss, and will have the least ability to pay. The impacts on jobs are a result of costs to businesses and households managing unreliable water delivery and wastewater treatment services. ASCE [22] suggested that the US could lose $\$ 18$ trillion in GDP in the next 10 years 
due to infrastructure deficiencies, including water and wastewater.

The robust infrastructure installed prior to 1950 has been a significant factor in economic development for many communities. But today, local budget growth rate has changed as local officials try to rein in costs. The Congressional Budget Office [23]) reports a decline in real public spending on transportation and water infrastructure since 2003, and that both construction and rehabilitation of has highways declined since 1959. The result is deteriorating infrastructure condition, the National Council on Public Works concluded their first assessment grade for infrastructure in the 1980s-piping was not discussed in this report. ASCE's first report card in 1998 did not express concern about piping system, but the overall grades were abysmal. Since that time the grades have not really improved for water and sewer systems [22] [24] [25] [26] [27] [28].

The growth in local public water spending from 1972 to 2010 was $7.6 \%$ year-over-year [29]. However, spending decreased 6\% between 2001 and 2010, and fell by $5 \%$ in 2012 [29]. Many utilities went negative on growth rates from 2009-2011 due to the Great Recession. Larger utilities can often weather such storms, but the majority of water utilities are small-serving populations of 10,000 or less. So how large is the deferred infrastructure backlog? In 1989, Duffy-Deno and Eberts [30] estimated the shortfall between investment needed to provide "adequate" public infrastructure and available revenues to fund these projects range from $\$ 17.4$ billion to $\$ 71.7$ billion annually by 2000 . For drinking water and wastewater systems, the "needs gap" has been estimated to be as high as $\$ 500$ billion over 20 years [31]. The American Water Works Association [32] estimated \$1 trillion in 2012 for all water systems. The US Council of Mayors [29] argued that a $\$ 111$ billion a year investment will not satisfy future demand. According to the Environmental Protection Agency's (EPA) most recent estimates, more than $\$ 655$ billion may be needed to repair and replace drinking water and wastewater infrastructure nationwide over the next 20 years. [33]. In 2013, ASCE predicted the annual amount for sustaining water delivery and wastewater treatment infrastructure was $\$ 84$ billion. Small water utilities may need an estimated $\$ 110$ billion for drinking water infrastructure and $\$ 33$ billion for wastewater infrastructure (for a total of $\$ 143$ billion [33]. Large water utilities-those serving populations of 100,000 or more-account for an estimated $\$ 145$ billion to repair and replace drinking water infrastructure and an estimated \$219 billion for wastewater infrastructure (for a total of $\$ 364$ billion [33]). In 2016, the USEPA estimated a $\$ 500$ billion need for infrastructure investment by 2025 . The USDA is planning to invest over $\$ 300$ million in rural water infrastructure [34].

This means a lot of investment is needed it our infrastructure systems are to continue to support economic development. As a result, a project was undertaken to look at a series of water and wastewater utilities in Florida to see how these trends might look. The goal of the project was to determine if there was data to indicate a change in the investment practices of utilities. A prior study by Bloetscher [35] [36] evaluated water and sewer utilities from a cost perspective. 
The following information was evident:

- The average daily water flows versus average daily sewer flows demonstrated that the customers within the service areas of the utilities for water and sewer are relatively consistent, so that any comparison made between these utilities does not have a significant distinguishing factor due to affluence or relative lack thereof.

- The comparative statistic that provided the best picture of the impact to the customer were the cost per thousand gallons for water treatment, water distribution, sewer collection and wastewater treatment, which clearly demonstrate the economy-of-scale of the larger utility operations versus small scale operations.

- The economy-of-scale arguments for utility operations were realized (see Figures 1-4). The data supports the long-held contention of the USEPA and

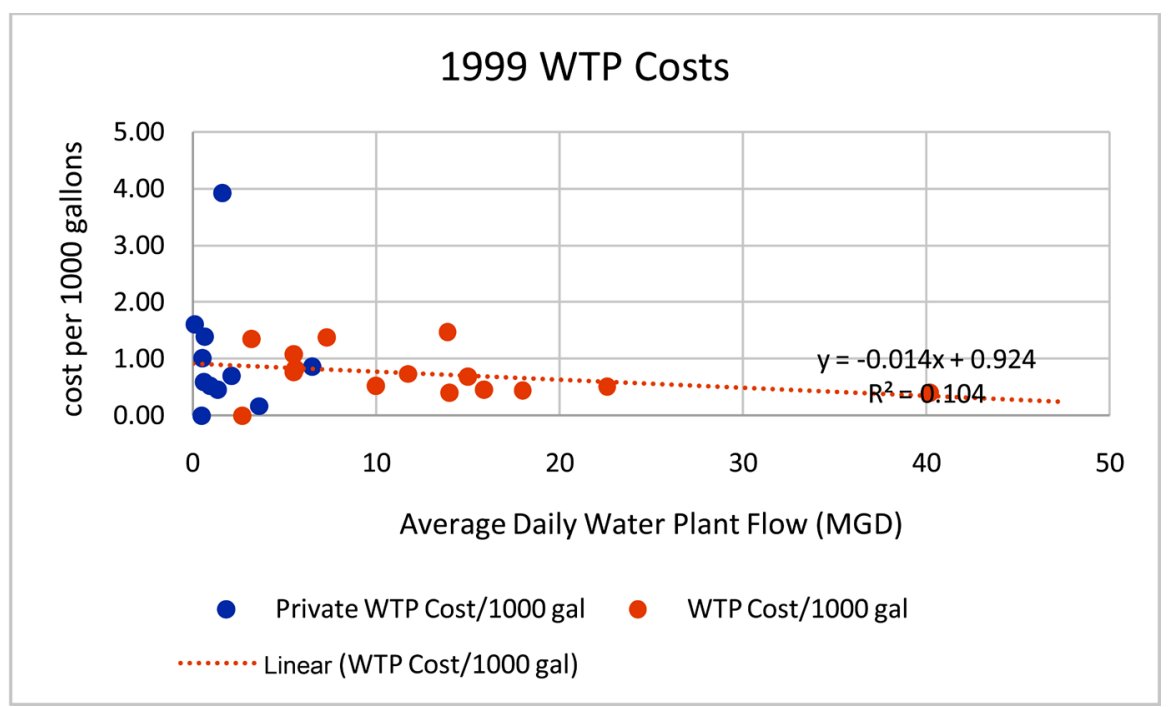

Figure 1. 1999 Water treatment costs per 1000 gallons compared to average daily water flows.

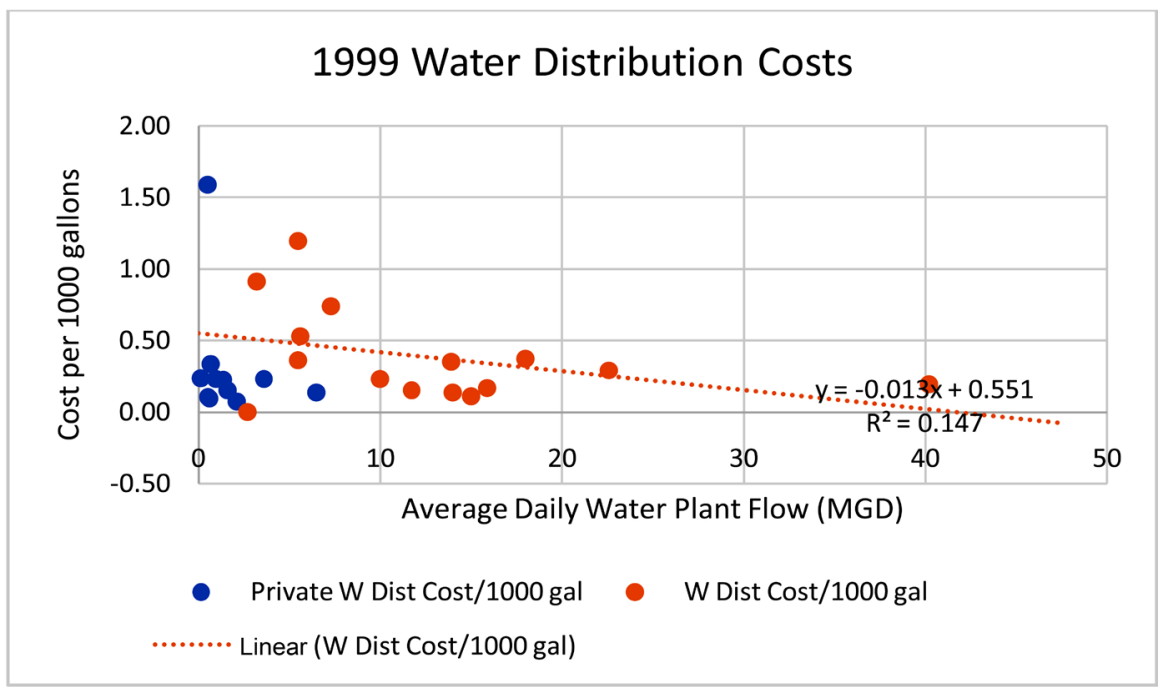

Figure 2. 1999 Water distribution costs per 1000 gallons compared to average daily water flows. 


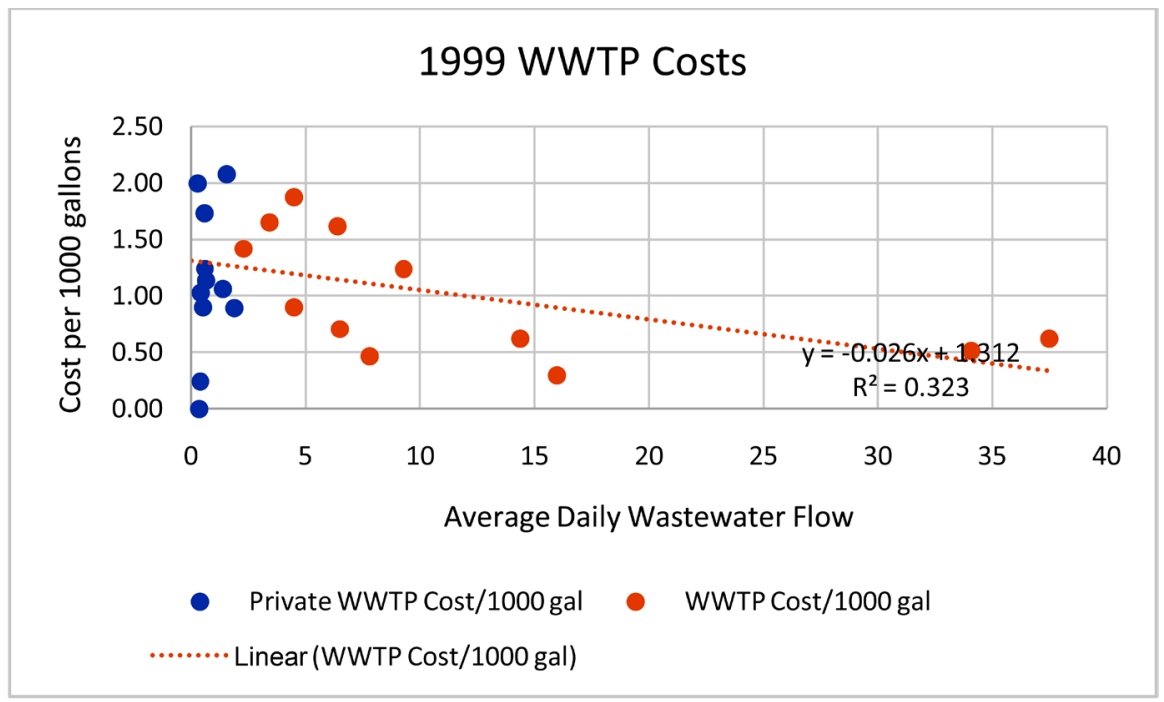

Figure 3. 1999 Wastewater treatment costs per 1000 gallons compared to average daily wastewater flows.

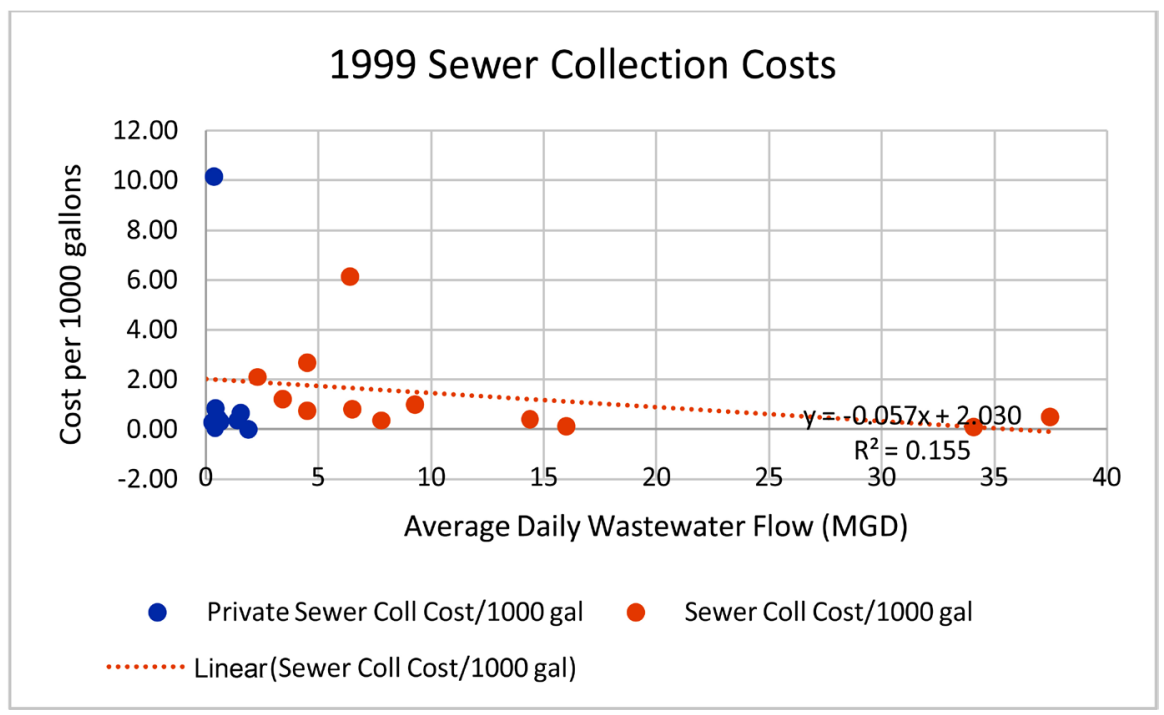

Figure 4. 1999 Sewer Collection costs per 1000 gallons compared to average daily wastewater flows.

other regulatory officials that smaller utilities simply do not have the cash flow to operate their systems efficiently.

- The newer systems have a lesser cost than the older systems, as measured in the cost to maintain miles of pipe, but this does not translate to plant operations costs.

- Generally, the rate structures are similar; that being that there is an availability charge and a volumetric charge. Given this fact, the economies-of-scale of the larger systems will permit them to fund more capital projects (or provide higher General Fund subsidies) than the smaller systems, and will permit more debt funding.

- The smaller utilities generally are accumulating enough costs to handle their 
operating requirements, but insufficient funds to utilize for reinvestment in the system.

- The larger systems raise significant revenues for the construction of improvements on the system (via RRI and bond funds), which is more than the other utilities generally do.

- Debt service appears to drive rates for most of the utilities regardless of the disparity between the size of the system and the cost per thousand gallons to produce, collect, and distribute or treat.

Bloetscher [35] [36] suggested that economies-of-scale created a situation where larger utilities had a competitive advantage over smaller utilities, yet an the utilities in an area tended to charge the same amount to their customers. That meant less money for capital. A second hypothesis to evaluate in this study is that the economic conditions changes since 1999 and now more funds are being diverted to the underlying general governments from the utilities, taking funding away from maintenance and capital spending has not increased. To evaluate these questions, the author reviewed the data from 1999 and compared it to 2017 using the same methods.

\section{Methods}

The dataset used for the 1997 and 1999 studies was expanded as trying to identify those utilities that might be at risk for failure requires more than just utility data-means could be developed to identify those utilities at risk for future infrastructure and/or financial crises, one could monitor them in more detail as a means to avoid such crises. The factors were expanded beyond the utility to include demographic and economical data: economic activity trends, income, poverty rate, unemployment rate, utility size, reserves, utility rates, history of rate increases, etc. Many are issues that are difficult to determine without significant work.

If all the data were available, the data could be used to develop an index as a means to evaluate risk. The results could be used to focus regulatory response, identify areas of need, and involved the banking community to address the high-risk cases. The banking industry has a means to evaluate their risk of non-payment using certain economic and social measures, while regulatory agencies use water quality. Neither fully develops the intersection of the economic, social and utility factors into one index. To begin such an analysis and provide some useful data, the data was gathered from 40 utilities in Florida. 2016 was used as the model year with the 2017 budget and 2016 CAFR. Among the issues to evaluate when looking at utility failure risk include:

1) Water rates (6000 gallons per month).

2) Water production-average daily flows reported by the utilities (in millions of gallons per day-MGD).

3) Water production trend (percent change per year).

4) Wastewater production trend (percent change per year). 
5) Budgets for water treatment (WTP), water distribution (WD), sewer collections (SC), wastewater treatment (WWTP), customer service (CS), administration and general fund transfers (Admin) - associated with a per thousand gallon allocation to customers.

6) Net plant assets (NPA) from the 2016 Comprehensive Annual Financial Report (CAFR) for each utility.

7) Replacement value (Repl) of assets-based on asset data from the CAFR and estimated costs in 2016 for providing infrastructure installations base don local knowledge of construction costs.

8) Capital expense-from the CAFR and budget.

9) Amount of debt as ratio to operating expenses (Debt/Exp) for the CAFR.

10) Fund balance (unrestricted reserves) from the CAFR (FB).

11) Net plant assets compared to estimated Replacement value.

12) Population-the percent change from the 2000 census and 2017 estimates.

13) Economic trend (percent change per year) based on income and population data.

14) Income trend-change between the 2000 census and 2017 census estimates.

Items 1 - 5 were used to evaluate how utilities compared to one another-the process was searching to validate the economy-of-scale argument that larger systems can provide services at lesser cost than smaller systems. Items $6-11$ were used to evaluate the amount of investment and potential value remaining in those systems. Items 12 - 14 were used to determine the economic productivity index of the community-were things better or worse for residents compared to other communities. The intent was to see if there were trends related to the general underinvestment across all system sizes. Correlation analysis via EXCEL ه was the methods of choice for this analysis. A trendline and $\mathrm{R}^{2}$ value were found for each, although the number of datapoints might improve the analysis.

One item that is difficult to assess is the value of investments that must be made by the utility system by reviewing the historical investments in the system. Such an analysis requires knowledge of year-by-year additions and retirements to the system by type and size of asset, which is rarely available in any utility organization. As a result, a simplified model was developed to address these concerns. To create the model, an estimate of the appropriate annual investment needs to be developed. By analyzing over 40 utility systems, $62 \%$ of their assets were piping. Therefore to provide a measurement of the appropriate amount of investment the following assumptions were made:

- 60 percent of assets were pipe with a life averaging 80 years,

- the remaining assets being "plants" with an average life of 40 years,

- Inflation prior was 3\% back to 1980 , and 5\% prior (matching CPI averages),

- All demands are currently met and there are no growth needs.

Based on these assumptions, the resulting for the appropriate amount of investment percentage was 45.6 percent to be current, with an average of $1.75 \%$ 
percent to be spent annually.

\section{Results}

For this study, the same comparative statistic of the impact to the customer were the cost per thousand gallons for water treatment, water distribution, sewer collection and wastewater treatment was undertaken (see Figures 5-8). Figures 5-8

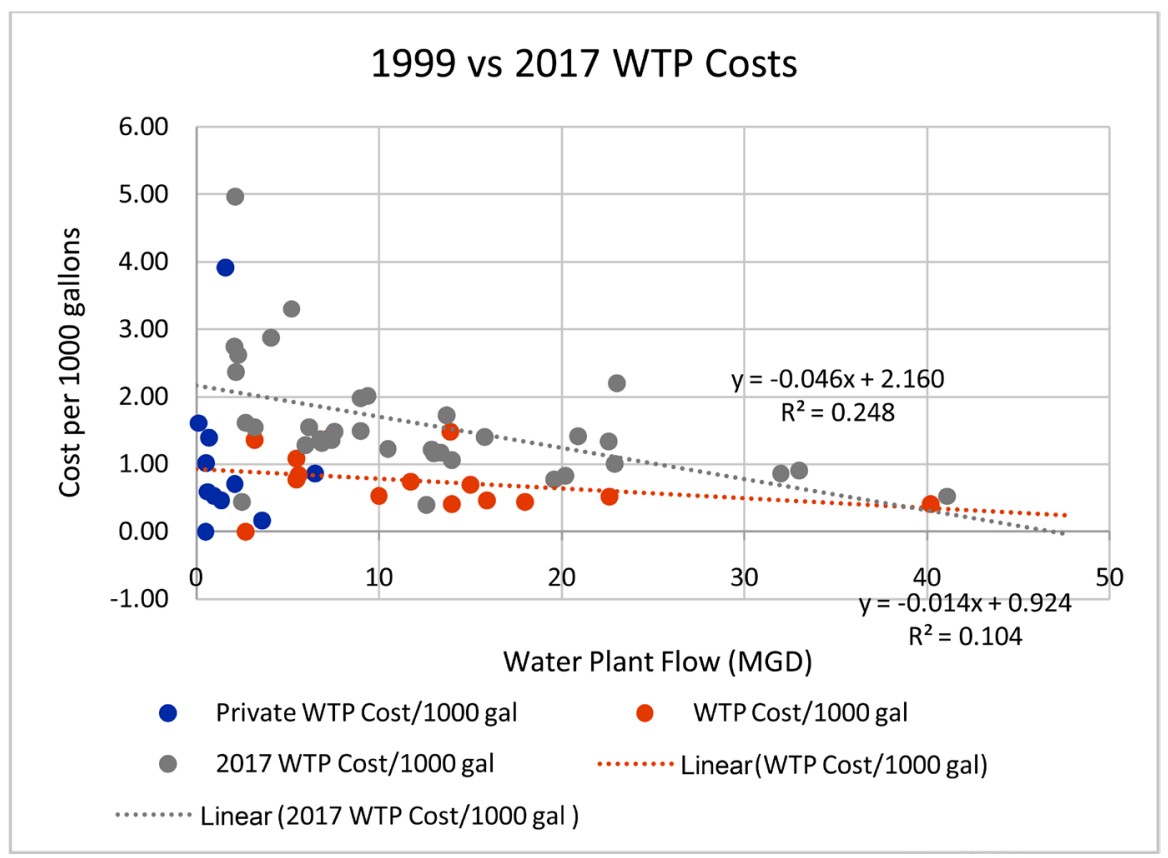

Figure 5. 1999 vs 2017 Water treatment costs per 1000 gallons compared to average daily water flows.

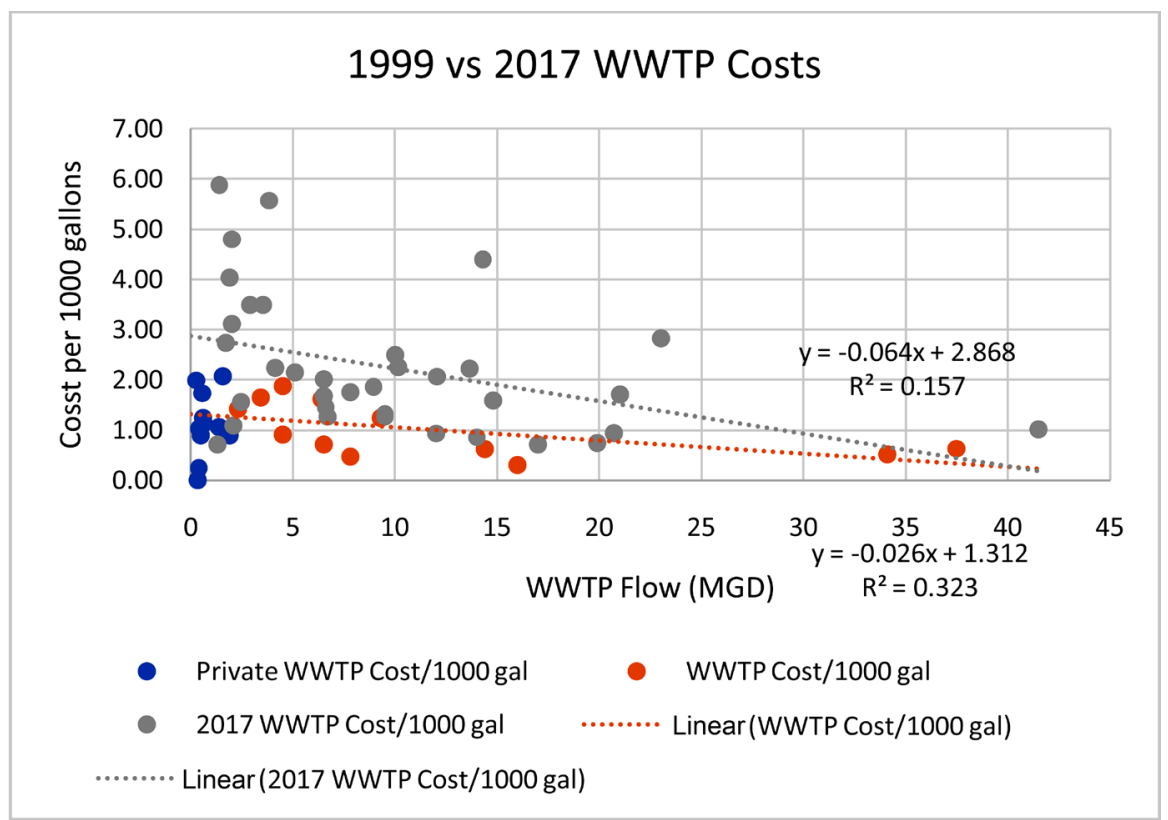

Figure 6. 1999 vs 2017 Wastewater treatment costs per 1000 gallons compared to average daily wastewater flows. 


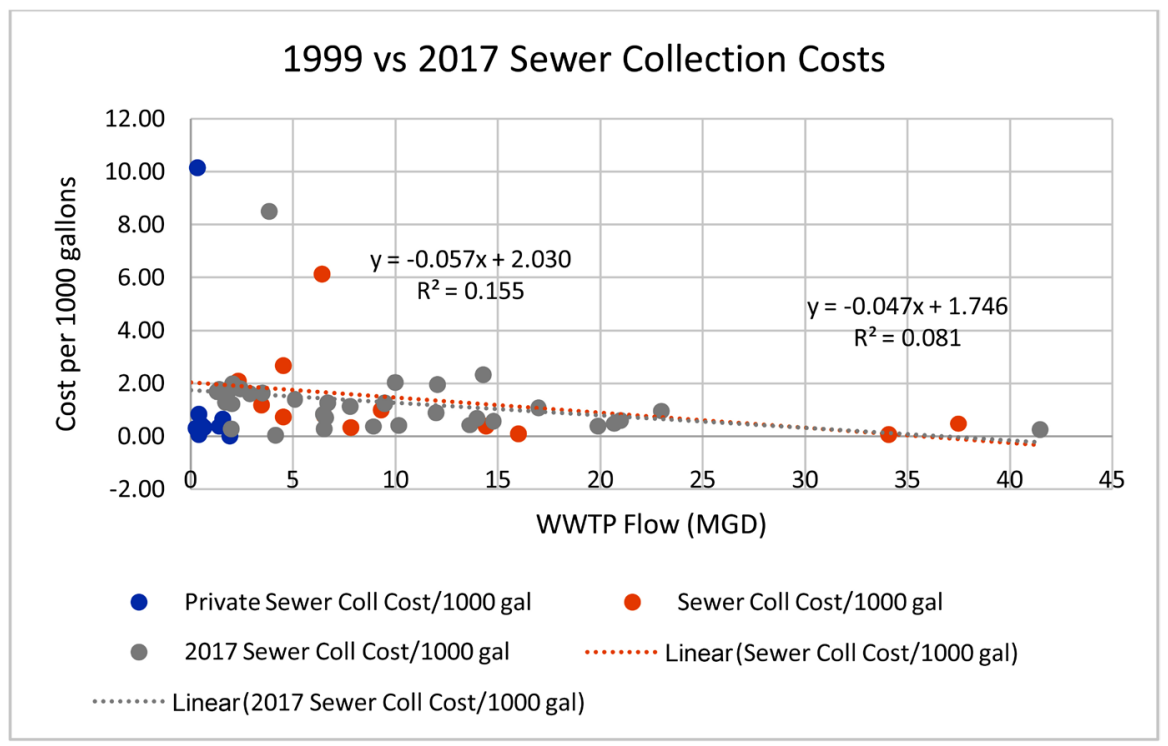

Figure 7. 1999 vs 2017 Sewer Collection costs per 1000 gallons compared to average daily wastewater flows.

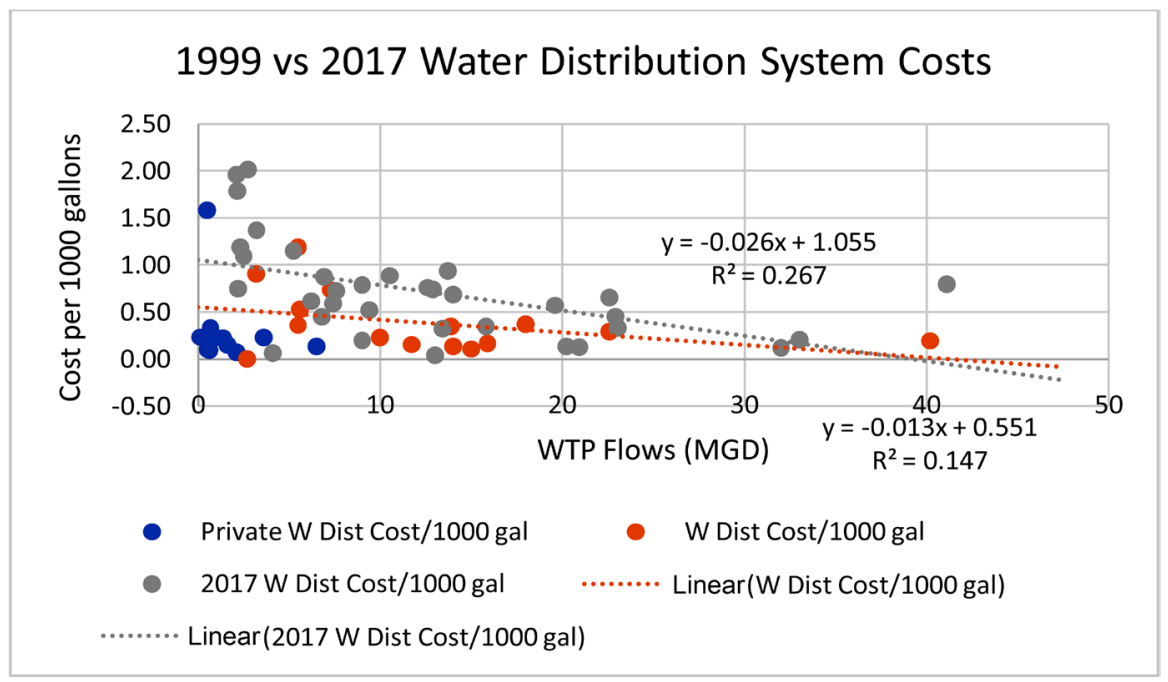

Figure 8. 1999 vs 2017 Water Distribution costs per 1000 gallons compared to average daily water flows.

show the 1999 versus 2017 data. As shown in the earlier work, the economy-of-scale arguments for utility operations were realized. The costs are higher as well for the smaller utilities, but not so much for larger utilities.

However, the amounts being transferred to the general funds we more (see Figure 9). Figure 10 shows that the smaller systems tend to have a higher percentage of transfers. An unanswered question is whether this phenomenon is a lingering impact of the 2008-2011 economic crisis where local governments balanced their general fund budgets via these transfers from the utility funds on the new status quo.

Figure 11 shows the results for the utilities. Only three utilities approximated the $45.6 \%$ value and all had recent ongoing, large construction projects while 


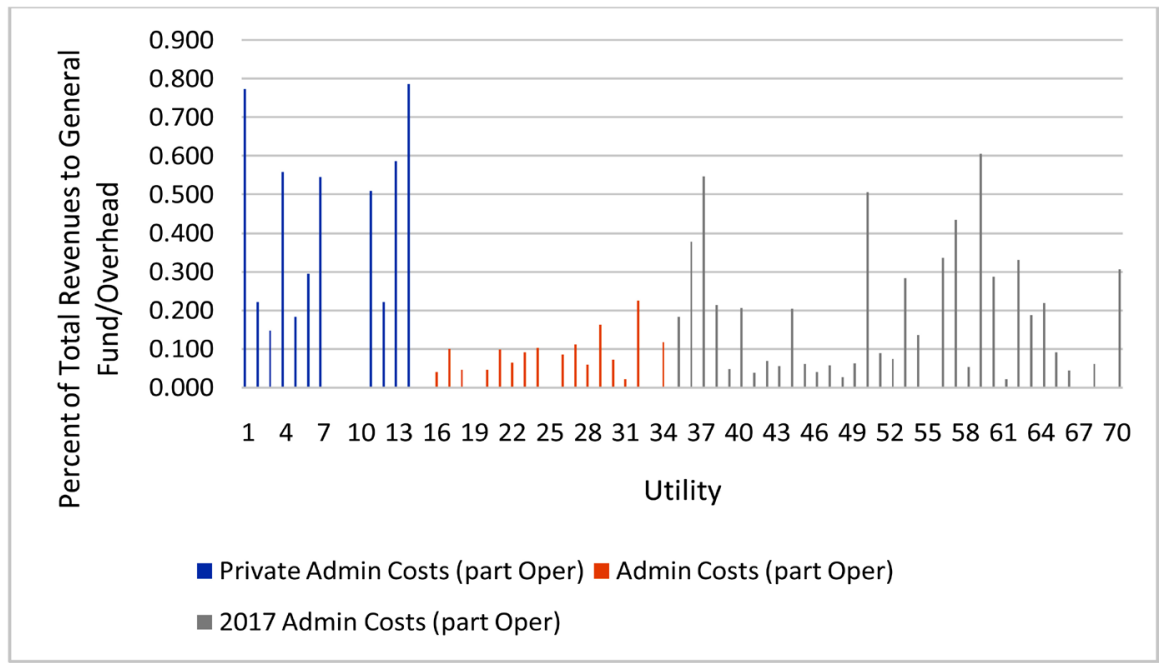

Figure 9. Public and private system transfer costs—1999 versus 2017 (all public systems)

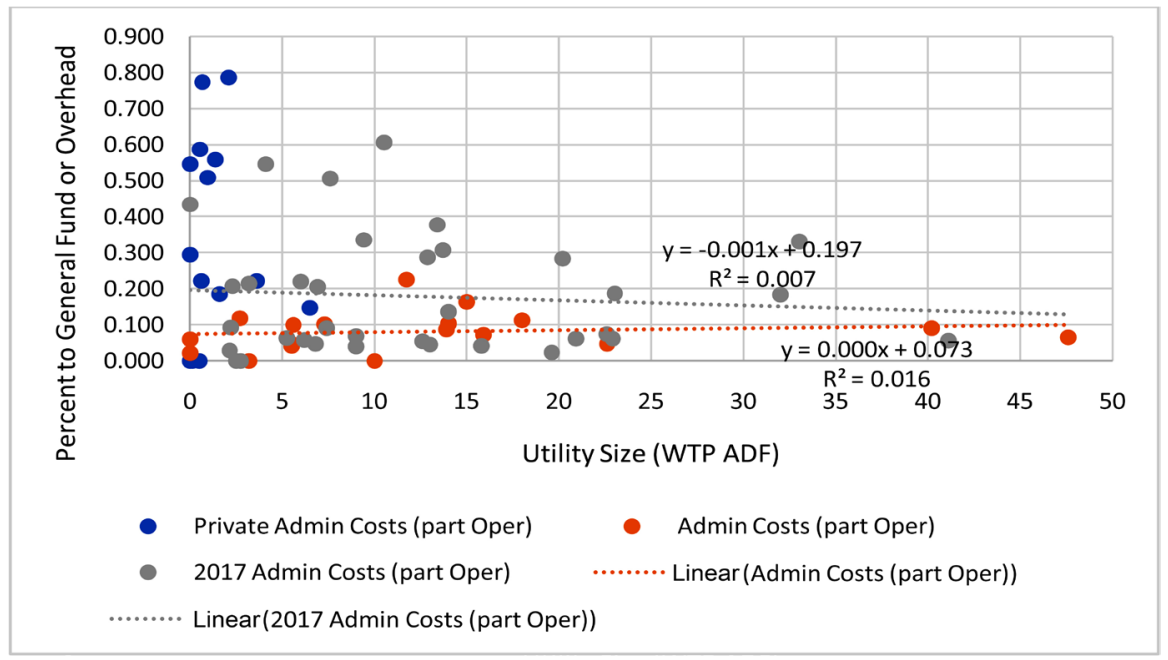

Figure 10. 1999 versus 2017-transfer percentage versus utility size (utility pater flows for size).

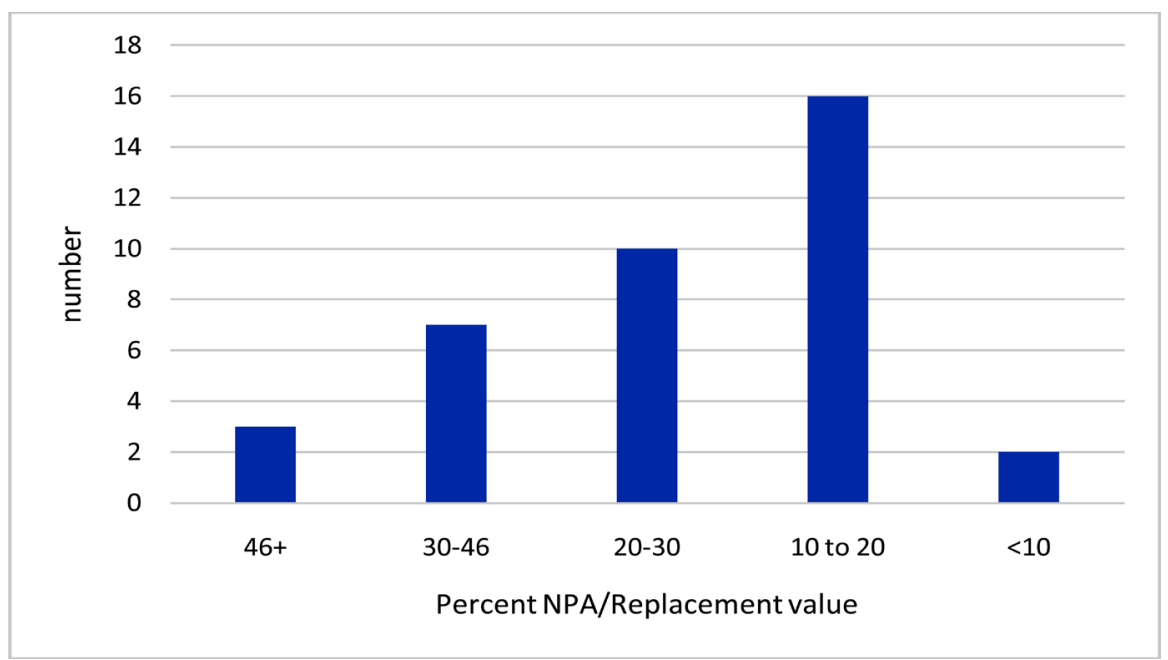

Figure 11. The number of utilities with net plant assets above 45.6 percent. 
two others were close. More than half were less than the $45.6 \%$ which does not bode well for long-term protection of the community. If the asset ratio is low, the next question is to see if utilities are under investing each year. Figure 12 shows that $13 \%$ of the utilities had no capital investments during 2016 , and $37 \%$ had invested less than the $1.75 \%$. Over $20 \%$ of the utilities had major capital projects going on and large percentages devoted to capital. When comparing these two factors, there was limited correlation (see Figure 13), so the conclusion was that investments were made in large blocks as opposed to more pay-as-you-go methods. This is partially confirmed by comparing the debt and the net plant asset/replacement value ratio (see Figure 14). The graph shows that higher debt related to higher replacement values, meaning the investments were more recent. It also suggests that there is much investment coming is some communities. To be fair a longer-term reporting period should be used in future

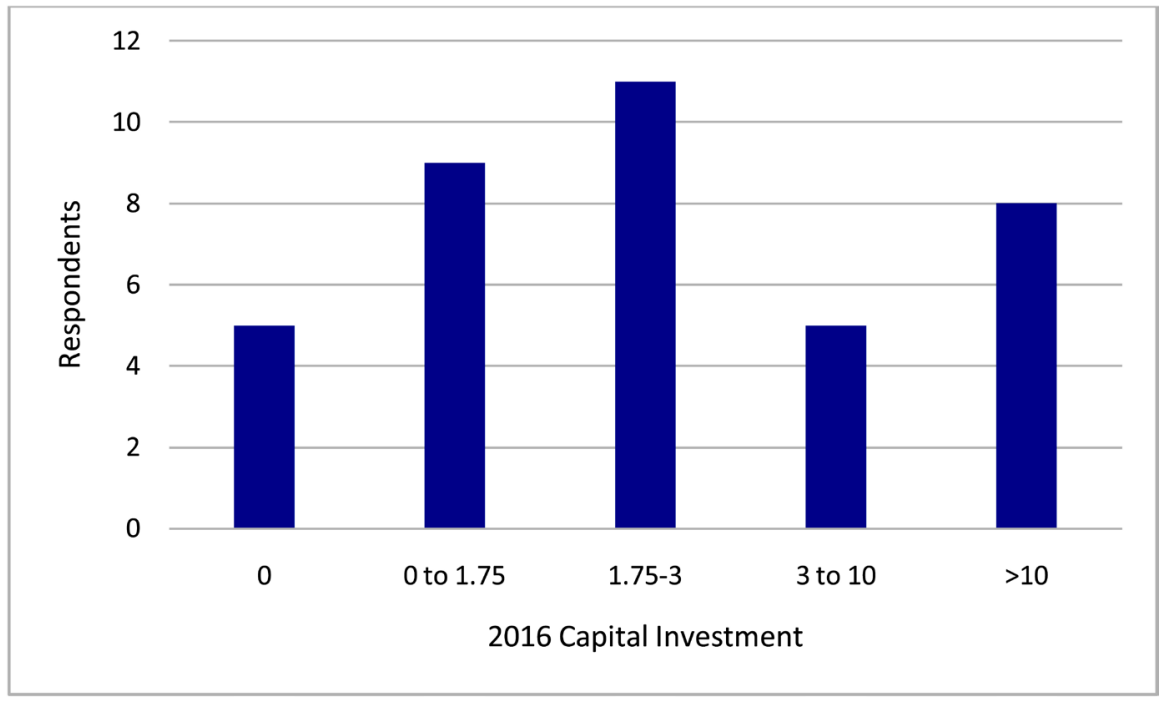

Figure 12. The amount utilities are investing annually in capital.

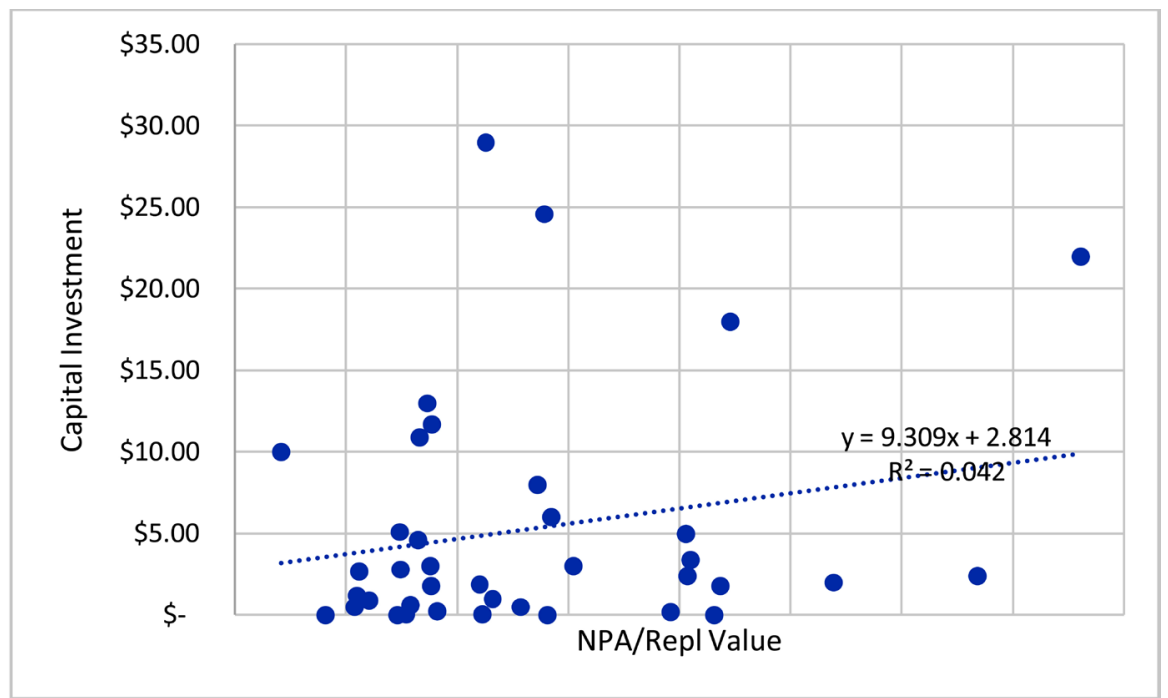

Figure 13. Annual investment versus net plant asset/replacement value ratio. 


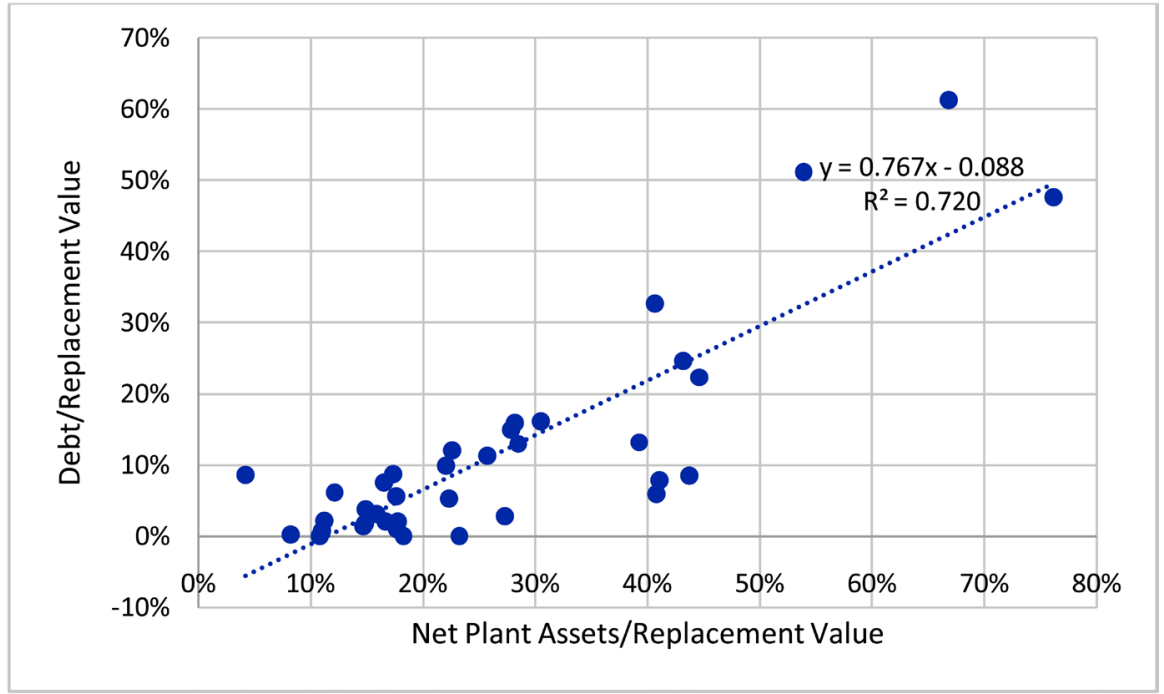

Figure 14. A comparison of the debt and the net plant asset/replacement value ratio.

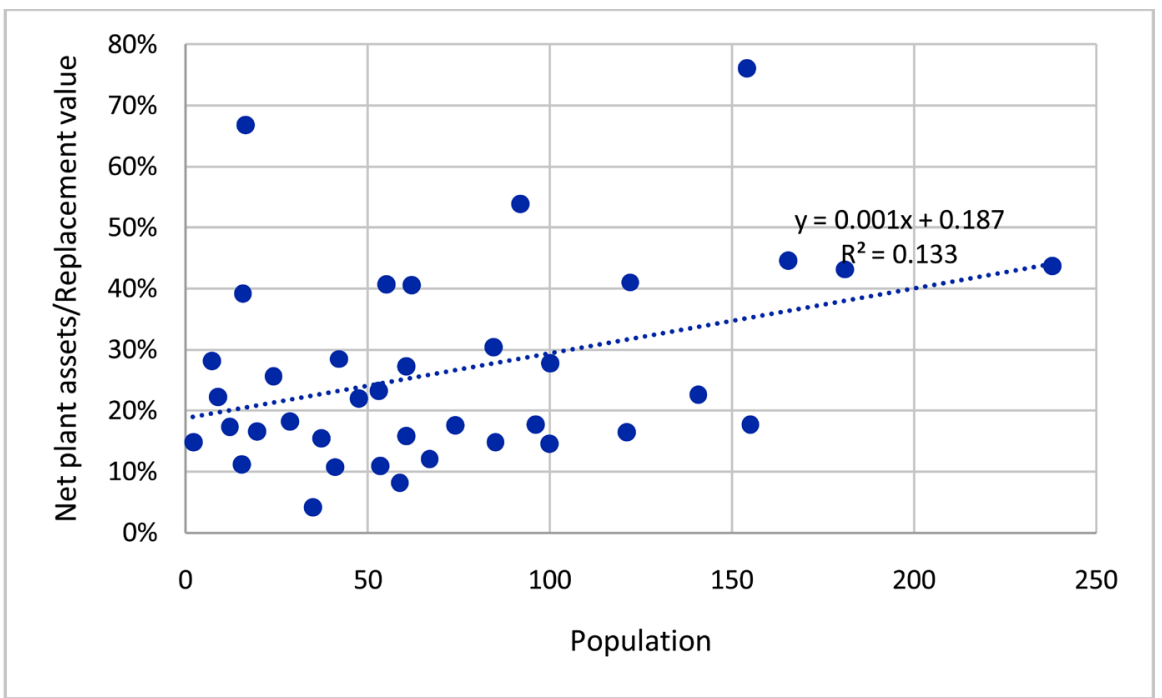

Figure 15. Population compared to the ratio of net plant assets/replacement.

work. To determine which communities, an analysis of the utility (population) versus net plant assets (NPA)/replacement value ratio. Figure 15 shows a degree of correlation that smaller communities have invested less as a percentage compared to larger utilities.

There are two potential, related reasons-resistance to rate increases and economic status. Khramov and Lee [37] developed an index that is used to look at countries. It is called the economic performance index or EPI. The EPI was calculated for each community. Note that data for increases in economic activity by community is very difficult to acquire, especially for small utilities. So income levels which area surrogate of sorts was used. Unemployment and inflation (pretty much a constant) were used. The index proposes the use of deficits, but none of the utilities can run a deficit, so this was ignored. Figure 16 shows the EPI versus the net plant assets/replacement value show a little more grouping 
favoring the communities with higher EPI values.

Cash on hand is needed to fund infrastructure projects. Figure 17 shows that the ratio of fund balance to annual budget versus EPI. This graph shows a slight trend of better community economics to increased fund balance. Likewise, Figure 18 shows that the larger utilities have higher amounts of fund balance, while Figure 19 indicates the relationship-utilities with higher net plant asset to replacement value ratios, have higher fund balance to budget ratios. Hence they invest and are healthier.

\section{Conclusions}

There are no zero risk options in the world, and this applies to avoiding the risk

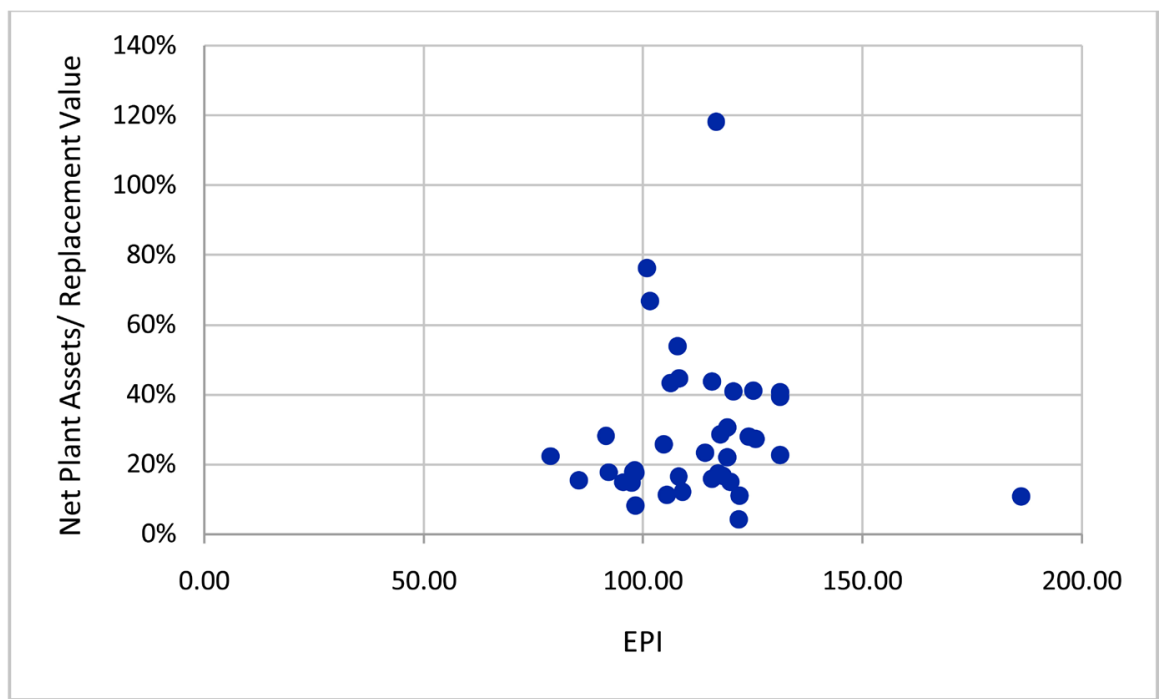

Figure 16. EPI measured against the net plant assets/replacement value.

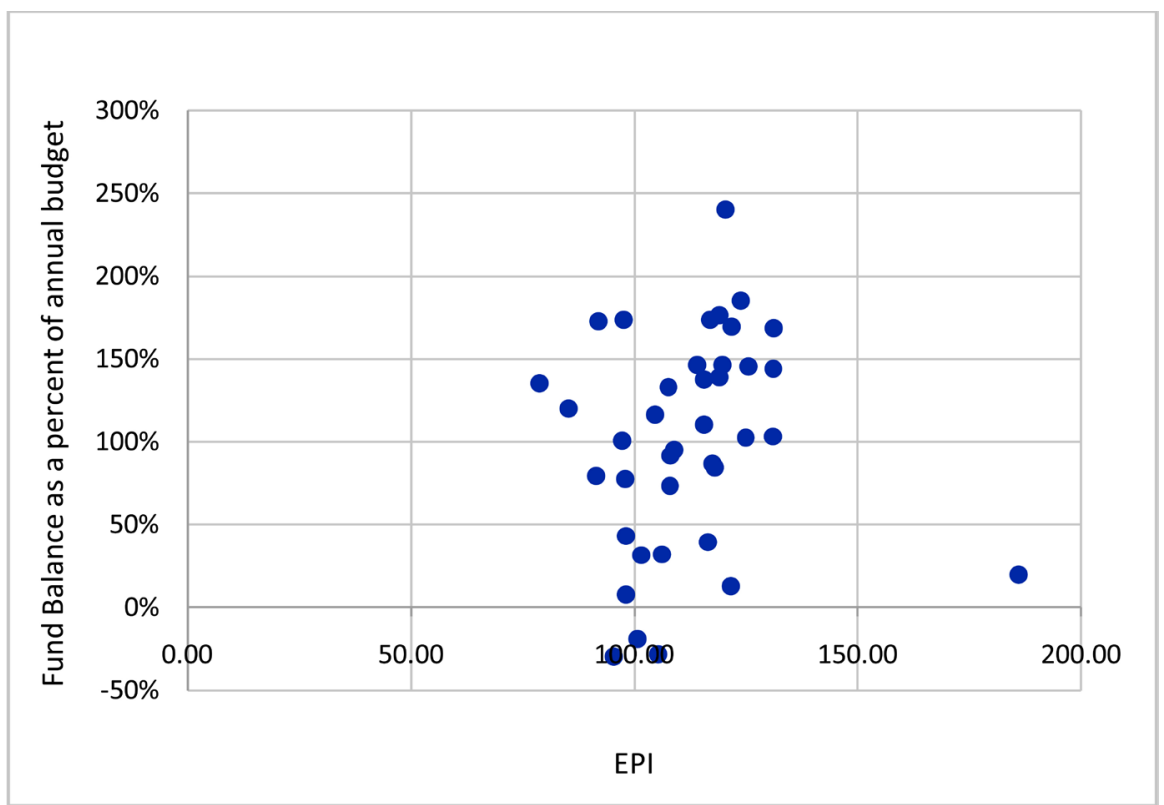

Figure 17. Ratio of fund balance to annual budget versus EPI. 


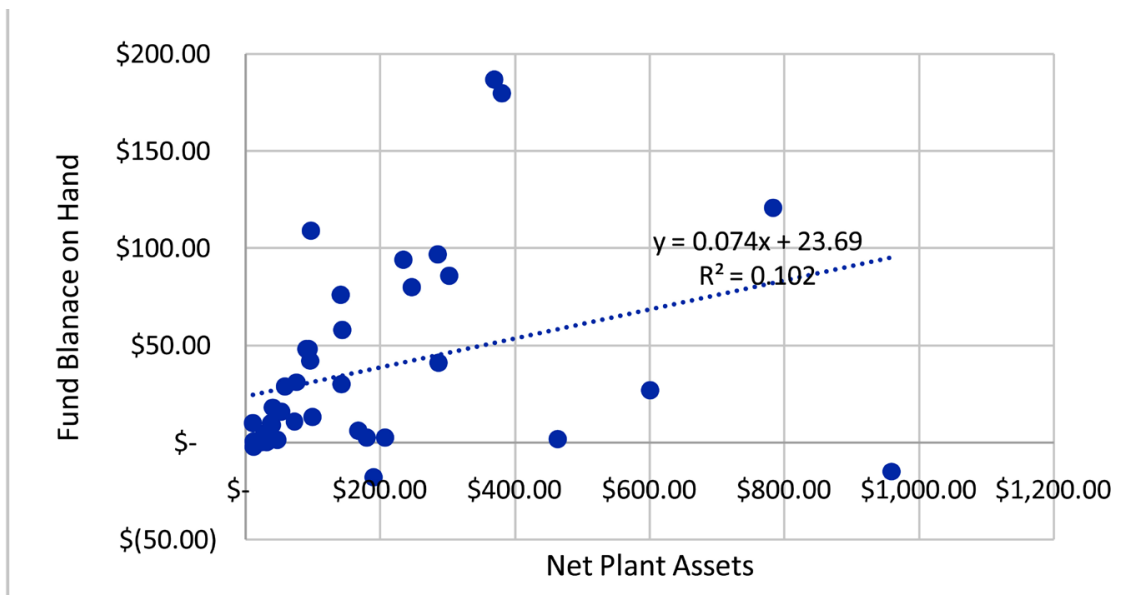

Figure 18. A comparison of net plant assets and on hand available fund balance.

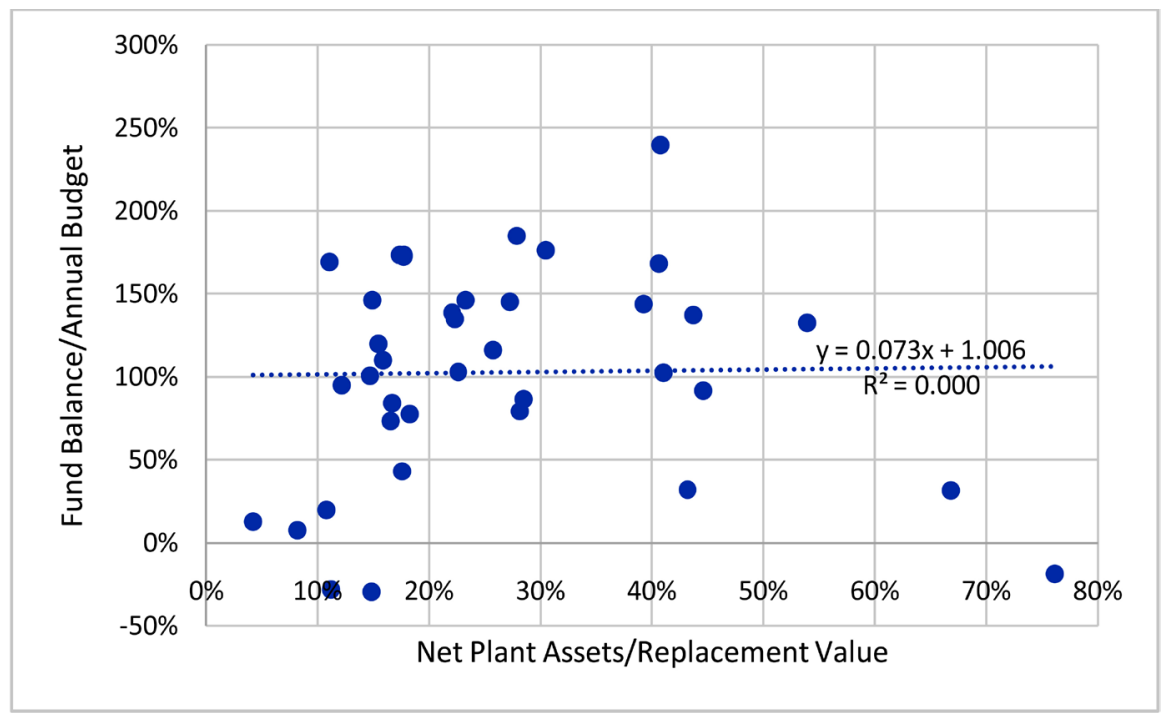

Figure 19. Higher net plant asset to replacement value ratios, indicate higher fund balance to budget ratios.

of failure with water and sewer utiltiies. The challenge is to try to minimize the potential for impacts as a result of breaks or failures, or to be able to project where failures are likely to occur so that appropriate steps can be taken to repair or replace assets likely to fail. Since infrastructure staffs are aware of the potential risks to providing service to the public they often include redundancy, additional personnel, extra parts and sensors to maintain equipment and be prepared for the inevitable failures that will occur. As a result, very few public health incidents occur in the United States in any given year, despite the potential for same. Elected and appointed officials need to recognize that it is the lack of spectacular failures with infrastructure systems that should be recognized and appreciated by the public, not the infrequent failures that no system can avoid.

However, while all utility system are created to develop safe, reliable, and financially self-supporting potable water and sanitary sewage systems which will 
meet the water and sewerage needs of the areas served by the utility, to ensure that existing and future utility facilities are constructed, operated and managed at the minimum cost to the users, and to develop a system that is compatible with the area's future growth. All systems experience failure, but for the most part, the failures are minor, last for a short time and have no long-lasting effects. These are quickly forgotten. Far fewer, are the cases where things go wrong, and there are consequences, but they are the ones people remember. Flint and Walkerton are two that remain in many people's minds. Trying to avoid being the next Flint is the key. This requires the appropriate expenditures for the repair and replacement of facilities beyond the useful life via annual allocations of funds.

The data gathered indicates that utilities are underfunded, and under-invested. To reduce potential health risks, this needs to change. At the same time, trends appear to be a key to assess the potential for at risk utilities. Hence a future project would review data for the past 15 - 20 years for trends, identify patterns of altered investments and denote how the 2008 financial crisis changed the utility finances. A road to recapture lost revenues and make the infrastructure more resilient can then be accomplished.

\section{Conflicts of Interest}

The authors declare no conflicts of interest regarding the publication of this paper.

\section{References}

[1] World Bank (1994) World Development Report 1994-Infrastructure for Development. The International Bank for Reconstruction and Development/The World Bank, Washington DC.

https://openknowledge.worldbank.org/bitstream/handle/10986/5977/WDR\%201994 $\% 20-\% 20$ English.pdf?sequence $=2$ \&isAllowed $=y$

[2] Kamps, C. (2005) The Dynamic Effects of Public Capital: VAR Evidence for 22 OECD Countries. International Tax and Public Finance, 12, 533-558. https://doi.org/10.1007/s10797-005-1780-1

[3] Grimsey, D. and Lewis, M.K. (2002) Evaluating the Risks of Public Private Partnerships for Infrastructure Projects. International Journal of Project Management, 20, 107-118. https://doi.org/10.1016/S0263-7863(00)00040-5

[4] Barro, R. (1990) Government Spending in a Simple Model of Endogenous Growth. Journal of Political Economy, 98, 102-125. https://doi.org/10.1086/261726

[5] Fedderke, J. and Bogetic, Z. (2006) Infrastructure and Growth in South Africa: Direct and Indirect Productivity Impacts of 19 Infrastructure Measures. Economic Research Southern Africa Working Paper No. 39, Forthcoming World Development. World Bank, Washington DC.

https://www.csae.ox.ac.uk/conferences/2007-EDiA-LaWBiDC/papers/020-Fedderke .pdf

[6] Barro, R. (1998) Notes on Growth Accounting. National Bureau of Economic Research Working Paper No. 6654. NBER, Cambridge. https://doi.org/10.3386/w6654

[7] Arrow, K. and Kurz, M. (1970) Public Investment, the Rate of Return and Optimal 
Fiscal Policy. Johns Hopkins.

[8] Borcherding, T.E. and Deacon, R.T. (1972) The Demand for the Services of NonFederal Governments. American Economic Review, 62, 842-853.

[9] Aschauer, D.A. (1987) Is Goverment Spending Stimulative? Federal Reserve Bank of Chicago Staff Memoranda.

[10] Aschauer, D. (1989) Is Public Expenditure Productive? Journal of Monetary Economics, 23, 177-200. https://doi.org/10.1016/0304-3932(89)90047-0

[11] Aschauer, D.A. (1990) Why Is Infrastructure Important? https://www.bostonfed.org/-/media/Documents/conference/34/conf34b.pdf

[12] Munnell, A.H. (1992) Infrastructure Investment and Economic Growth. Journal of Economic Perspectives, 6, 189-198. https://doi.org/10.1257/jep.6.4.189

[13] Stephanades, Y.J. (1990) Distributional Effects of State Highway Investment on Local and Regional Development. Transportation Research Record, 1274, 156-164.

[14] Stephanades, Y.J. and Eagle, D.M. (1986) Time-Series Analysis of Interactions between Transportation and Manufacturing and Retail Employment. Transportation Research Record, 1074, 16-24.

[15] Eberts, R.W. (1990) Public Infrastructure and Regional Economic Activity. https://fraser.stlouisfed.org/title/1328/item/4443/toc/77342\#scribd-open

[16] Bougheas, S., Demetriades, P.O. and Mamuneas, T.P. (2000) Infrastructure, Specialization, and Economic Growth. Canadian Journal of Economics, 33, 506-522. https://doi.org/10.1111/0008-4085.00026

[17] Moomaw, R.L., Mullen, J.K. and Williams, M. (1995) The Interregional Impact of Infrastructure Capital. Southern Economic Journal, 61, 830-845. https://doi.org/10.2307/1061001

[18] Pereira, A.M. (2001) Public Investment and Private Sector Performance: International Evidence. Public Finance and Management, 1, 261-277.

[19] Krugman, P. (2014) The Stimulus Tragedy op-ed Appears. New York Times, A25.

[20] Kavoussi, B. (2011) Paul Krugman: U.S. Economy Needs “The Financial Equivalent of War". http://www.huffingtonpost.com/2011/09/28/paul-krugman-spending_n_984921.ht $\underline{\mathrm{ml}}$

[21] Munnell, A. and Cook, L.M. (1990) How Does Public Infrastructure Affect Regional Economic Performance? New England Economic Review, 1990, 11-33.

[22] American Society of Civil Engineers (ASCE) (2017) Report Card for America's Infrastructure. ASCE, Alexandria. https://www.infrastructurereportcard.org/

[23] Congressional Budget Office (2015) Public Spending on Transportation and Water Infrastructure, 1956 to 2014. CBO, Washington DC.

[24] American Society of Civil Engineers (ASCE) (2001) 2001 Report Card for America's Infrastructure. ASCE, Alexandria.

http://www.infrastructurereportcard.org/making-the-grade/report-card-history/200 1-report-card/

[25] American Society of Civil Engineers (ASCE) (2005) Report Card for America's Infrastructure. 2003 Progress Report, ASCE, Alexandria.

http://www.infrastructurereportcard.org/making-the-grade/report-card-history/200 5-report-card/

[26] American Society of Civil Engineers (ASCE) (2009) 2009 Report Card for America's Infrastructure. ASCE, Alexandria. 
http://www.infrastructurereportcard.org/2009/

http://www.infrastructurereportcard.org/making-the-grade/report-card-history/200 9-report-card/

[27] American Society of Civil Engineers (ASCE) (2011) Failure to Act: The Economic Impact of Current Investment Trends in Water and Wastewater Infrastructure. ASCE, Alexandria.

[28] American Society of Civil Engineers (2013) 2013 Report Card for America's Infrastructure. http://www.infrastructurereportcard.org/a/\#p/home

[29] US Council of Mayors (2015) Struggling Local Government Finances and Decelerating Public Water Investment. US Council of Mayors, Washington DC.

[30] Duffy-Deno, K.T. and Eberts, R.W. (1989) Public Infrastructure and Regional Economic Development: A Simultaneous Equations Approach. Working Paper 8909, National Science Foundation under Grant ${ }^{\star}$ SES-8414262-01, Federal Reserve Bank of Cleveland, Cleveland. https://fraser.stlouisfed.org/title/4494/item/494518\#scribd-open

[31] Anderson, R.F. (2010) Trends in Local Government Expenditures on Public Water and Wastewater Services and Infrastructure: Past, Present and Future. The U.S. Conference of Mayors-Mayors Water Council.

https://www.circleofblue.org/wp-content/uploads/2013/06/USMayors_Growth-in-L ocal-Government-Spending-on-Water-and-Wastewater.pdf

[32] AWWA (2012) Buried No Longer: Confronting America's Water Infrastructure Challenge. AWWA, Denver.

[33] GAO (2017) Drinking Water and Wastewater Infrastructure: Information on Identified Needs, Planning for Future Conditions, and Coordination of Project Funding. GAO-17-559 GAO, Washington DC.

[34] USDA (2016) USDA Is Planning to Invest over \$300 Million in Rural Water Infrastructure.

https://www.usda.gov/media/press-releases/2016/11/01/usda-announces-331-millio $\underline{\text { n-investment-clean-water-infrastructure }}$

[35] Bloetscher, F. (1999) Issues of Concern in the Evaluation of Any Service Delivery Mechanism. FSAWWA Annual Conference Proceedings, Orlando, December 1999.

[36] Bloetscher, F. (1997) Comparative Analysis of South Broward County Utility System Operations. FSAWWA Specialty Conference Proceedings, Clearwater, November 1997.

[37] Khramov, V. and Lee, J.R. (2013) The Economic Performance Index (EPI): An Intuitive Indicator for Assessing a Country's Economic Performance Dynamics in an Historical Perspective. IMF Working Paper No. 13/214. 